\title{
Effectiveness of Quality of Service towards Commitment of Suppliers with Reference to SME's in Automobile Industry
}

\author{
Rangaraju K ${ }^{1}$, V. R. Nedunchezhian², \& P. K. Suresh Kumar ${ }^{3}$ \\ ${ }^{1}$ Research Scholar, College of Management \& Commerce, Srinivas University, Mangalore - \\ 575001 , India. \\ E-mail: rajlakmi6@gmail.com \\ ${ }^{2}$ Professor and Head, Center Head Finance, KCT Business School, Coimbatore-641049, \\ India. \\ E-mail: dirvrn@yahoo.co.in \\ ${ }^{3}$ Research Professor, College of Management and Commerce, Srinivas University, Mangalore \\ - 575 001, India. \\ E-mail: cdrsuresh@yahoo.co.in
}

Area/Section: Business Management.

Type of the Paper: Empirical Research.

Type of Review: Peer Reviewed as per $|\mathrm{C}| \mathrm{O}|\mathrm{P}| \mathrm{E} \mid$ guidance.

Indexed in: OpenAIRE.

DOI: http://doi.org/10.5281/zenodo.4112314

Google Scholar Citation: IJMTS.

\section{How to Cite this Paper:}

Rangaraju K, Nedunchezhian, V. R. \& Suresh Kumar, P. K. (2020). Effectiveness of Quality of Service towards Commitment of Suppliers with Reference to SME's in Automobile Industry. International Journal of Management, Technology, and Social Sciences (IJMTS), 5(2), 216232. DOI: http://doi.org/10.5281/zenodo.4112314

International Journal of Management, Technology, and Social Sciences (IJMTS) A Refereed International Journal of Srinivas University, India.

(C) With Author.

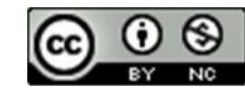

This work is licensed under a Creative Commons Attribution-Non-Commercial 4.0 International License subject to proper citation to the publication source of the work.

Disclaimer: The scholarly papers as reviewed and published by the Srinivas Publications (S.P.), India are the views and opinions of their respective authors and are not the views or opinions of the SP. The SP disclaims of any harm or loss caused due to the published content to any party. 


\title{
Effectiveness of Quality of Service towards Commitment of Suppliers with Reference to SME's in Automobile Industry
}

\author{
Rangaraju K' 1 , V. R. Nedunchezhian², \& P. K. Suresh Kumar ${ }^{3}$ \\ ${ }^{1}$ Research Scholar, College of Management \& Commerce, Srinivas University, Mangalore - \\ 575 001, India. \\ E-mail: rajlakmi6@gmail.com \\ ${ }^{2}$ Professor and Head, Center Head Finance, KCT Business School, Coimbatore-641049, \\ India. \\ E-mail: dirvrn@yahoo.co.in \\ ${ }^{3}$ Research Professor, College of Management and Commerce, Srinivas University, Mangalore \\ - 575 001, India. \\ E-mail: cdrsuresh@yahoo.co.in
}

\begin{abstract}
ABSTACT
Service quality is a focused evaluation that reflects the vendor's perception of specific dimensions of service. Though there is a problem with the automobile industry Covid-19 pandemic the sector may grow further in near future. The main objective is to examine the essential dimensions of service quality i.e. RATER- Reliability, assurance, tangibles, empathy and responsiveness of SME's in the automobile industry and its effect on vendor's satisfaction and to find out the perception of suppliers towards supply chain with the companies. For this, a sample of 50 was collected from the respondents were percentage analysis, Descriptive statistics, Multiple regression, Kruskal Wallis test, and one-way ANOVA were used as tools to analyse the data. The conclusion is that dimensional factors level of acceptance towards sourcing products from a limited number of suppliers, level of acceptance towards establishing clear criteria, and level of acceptance towards Suppliers collaborating with suppliers in materials are taken for decision making process of the study. It also reveals that while taking a decision on these dimensions the factor frequency of making supply should be taken for decision making process of the study.
\end{abstract}

Keywords: Service quality, Automobile industry, Supplier commitment.

\section{INTRODUCTION TO THE CONCEPT OF STUDY:}

In today's finicky market, customers will settle for nothing less. The client is at a recognized relatively belatedly he will be the ruler. Typically, the customer's range of one particular enterprise above an additional since his or her main loan provider is dependent upon concerns associated with program top quality instead of some other matter. High quality regarding assistance is really an extensive expression which is used in the customer support assessments as well as in scientific assessments. In the apps, the standard of the provider must choose computing the particular occurrence involving problems in just a method of which lead to typically the design associated with problems for the user. The purpose of virtually any high quality associated with company assessment is to reduce the particular relative incidence regarding transmitting concerns plus the mistake costs which could end result. Thus, the study is to find the impact of the quality of service provided by the SME's in the automobile industry towards preference and contact maintained by large scale companies in the automobile industry with their current suppliers. 


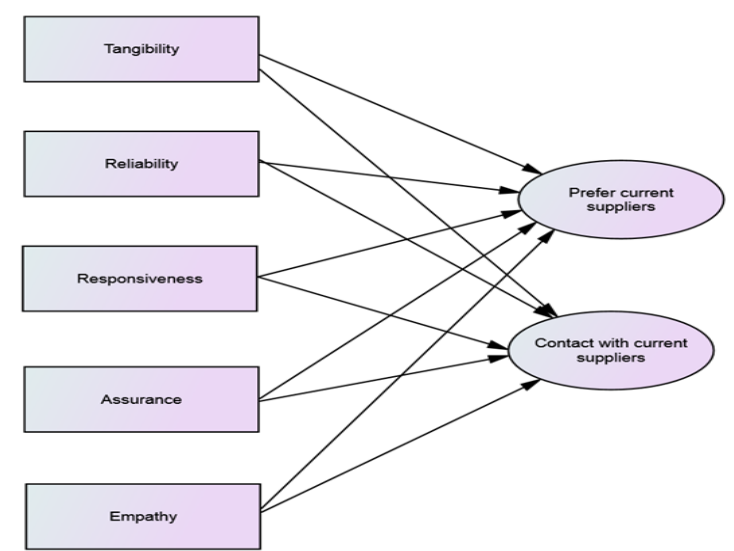

Chart 1: Conceptual framework

\section{Reliability:}

This dimension can be proven to contain the best effect relating to consumer knowledge regarding high quality. It's the capacity to execute the particular offers program dependably together with precisely. Typically, the consistency sizing, which will assure well-timed shipping and delivery, again and again, assists the service agency to satisfy the consumer expected values completely on the least expensive amount of service plan expectancy.

\section{Responsiveness:}

It does not take readiness for the support firm's staff members to assist consumers and supply them with a quick product. The shoppers might have worries, unique tickets, issues, and so forth Actually every single client could have troubles associated with her or his individual. As the front-end worker might have been taught or even outfitted to supply standard solutions, the purchasers wish these to rise above this kind of limitation. Is it doesn't motivation to assist the client or perhaps motivation to be that will additional yardage which is responsiveness. The 2 nd facet of responsiveness is going to be a quick reaction to a client to make certain. Whenever reaction is going to be postponed buyers normally manages to lose fascination.

\section{Assurance:}

This thought as the power from the firms to be able to motivate put your confidence in addition to selfconfidence within the company shipping. That identifies information and even due to the particular system firm's workers and the capability to really encourage put their trust in plus self-assurance inside the consumer in the direction of the firms. This particular dimension is recognized as important just for products that will require risky since the buyer is probably not in a position to examine the many questions mixed up in the method simply by all of them. Whenever potential customers listen to these people regarding the organizations and your reasonable shipping and delivery, they will experience given the assurance together to create a better outlook for the corporations.

\section{Empathy:}

This appertains to the consumer personalized consideration the particular system company offers every client. Whenever a provider places themselves within the shoes and boots of the clients, he might view the customer's perspective much better. The moment consumers believe that the particular service provider is definitely producing the greatest work to determine their own standpoint, it might be good enough for some.

\section{Tangibles:}

This describes bodily services, accessories, and look of the system firm's workers. The responsibility belonging to the concrete and even actual physical proof of something is without a doubt multipurpose. Tangibles give you the client evidence of the standard of assistance. 


\section{STATEMENT OF THE PROBLEM:}

SME's in the automobile industry plays a key role in the development of automobile companies across the country. Though the companies have limited employees they try to satisfy the need of automobile companies in a faster and effective way. Sometimes there may be a lag towards satisfying the vendor needs and all those activities are governed by employees working in large scale companies as they do have good connectivity with their vendors. Hence the study is conducted based on the following problems,

- Whether the companies who outsource their job orders to SME's are satisfied based on the service quality provided by SME's?

- What is the perception of employees who work in large scale automobile companies towards the quality of service provided by suppliers?

- Do service quality provided by the suppliers have an impact on the affective commitment of suppliers?

\section{OBJECTIVES OF THE STUDY:}

- To examine the essential dimensions of service quality and its impact towards i.e. RATERReliability, assurance, tangibles, empathy and responsiveness of SME's in the automobile industry and its effect on customer satisfaction.

- To analyse the level of perception of the employees towards the quality of suppliers.

- To find out the impact of the quality of service towards the affective commitment of suppliers.

\section{SCOPE OF STUDY:}

The scope of this research is to identify the service quality of SME's in the automobile industry. The study will help the SME's in the automobile industry to know about the quality of service provided to their vendor companies to rectify their errors in the future period of time.

\section{REVIEW OF LITERATURE:}

Automobile industry is one of the most important industry which creates plenty of job opportunities and plays a major role towards contributing to GDP. As the competition is getting increased every day the quality of service provided to the customers is considered as a key factor towards the industry and for the same, the companies are outsourcing their job work SME's across the country were the SME's has to satisfy the requirements of large scale companies so that they can satisfy their clients requirement and the same has been taken as a concept towards the study. To analyse the concepts of the study the following reviews have been taken into consideration.

Table 1 : Reviews related to the concept

\begin{tabular}{|l|l|l|}
\hline Research Area & Research focus & Reference \\
\hline Automobile industry & Service quality & Baidoo, F et al. (2015). [1] \\
\hline $\begin{array}{l}\text { SME in automobile } \\
\text { industry }\end{array}$ & Maintenance \& repair service & Baidoo, F. et al. (2017). [2] \\
\hline B2B technology & $\begin{array}{l}\text { Quality of service based on customer } \\
\text { satisfaction }\end{array}$ & $\begin{array}{l}\text { Bruce C.Y. Lee et al. (2019). } \\
\text { [3] }\end{array}$ \\
\hline Passenger bike & Preference towards brand & $\begin{array}{l}\text { C Dharmaraj et al. (2009). } \\
\text { [4] }\end{array}$ \\
\hline $\begin{array}{l}\text { Conceptual reviews with } \\
\text { SME }\end{array}$ & Knowledge management of SME's & $\begin{array}{l}\text { Cerchione, R et al. (2016). } \\
\text { [5] }\end{array}$ \\
\hline $\begin{array}{l}\text { Conceptual reviews on } \\
\text { operation management }\end{array}$ & Continuous Improvement performance & $\begin{array}{l}\text { Ebrahimi, M et al. (2013). } \\
\text { [6] }\end{array}$ \\
\hline Service sector & $\begin{array}{l}\text { Comparison between quality of service } \\
\text { and satisfaction of customers }\end{array}$ & $\begin{array}{l}\text { G.S. Sureshchandar et al. } \\
\text { (2002) [7] }\end{array}$ \\
\hline Indian SME's & $\begin{array}{l}\text { Service quality based on employee } \\
\text { effectiveness }\end{array}$ & $\begin{array}{l}\text { Gandhi, S. K et.al., (2017) } \\
\text { [8] }\end{array}$ \\
\hline
\end{tabular}




\begin{tabular}{|c|c|c|}
\hline Small-Scale & Employee service quality & Gandhi, S et.al., (2018) [9] \\
\hline $\begin{array}{l}\text { Global market } \\
\text { segmentation }\end{array}$ & Perceived service quality & $\begin{array}{l}\text { James Agarwal et.al., (2010) } \\
{[10]}\end{array}$ \\
\hline Automobile industry & Effectiveness of TQM & Kalra, N et.al., (2013) [11] \\
\hline Thai retail stores & Vision effects & $\begin{array}{l}\text { Kantabutra Sooksan (2008) } \\
{[12]}\end{array}$ \\
\hline SME & Service fusion & $\begin{array}{l}\text { Kowalkowski, C et.al., } \\
\text { (2013) [13] }\end{array}$ \\
\hline $\begin{array}{l}\text { Auto component with } \\
\text { SME in Bangalore }\end{array}$ & $\begin{array}{l}\text { Influence of Technology innovation on } \\
\text { growth }\end{array}$ & $\begin{array}{l}\text { Krishnaswamy, K. N et.al., } \\
\text { (2014) [14] }\end{array}$ \\
\hline Retail stores & $\begin{array}{l}\text { Efficiency based on benchmarking } \\
\text { schemes }\end{array}$ & $\begin{array}{l}\text { Mishra Kumar Rohit (2014) } \\
\text { [15] }\end{array}$ \\
\hline SME & $\begin{array}{l}\text { Role of satisfaction, quality of service } \\
\text { and trust }\end{array}$ & Rajic, T C et.al., (2016) [16] \\
\hline SME in Iran & $\begin{array}{l}\text { Determinants of TQM and quality of } \\
\text { service }\end{array}$ & $\begin{array}{l}\text { Ramezani, H et.al., (2013) } \\
\text { [17] }\end{array}$ \\
\hline Quality of service & Service quality in B2B & Spiros Gounaris (2005) [18] \\
\hline SME & $\begin{array}{l}\text { Retail mix and quality of service } \\
\text { influence towards satisfaction }\end{array}$ & $\begin{array}{l}\text { Subroto Budiarto et.al., } \\
\text { (2008) [19] }\end{array}$ \\
\hline SME automobile industry & SMEs and Entrepreneurship & $\begin{array}{l}\text { Tangkitvanich, S. (2004) } \\
{[20]}\end{array}$ \\
\hline Indian SME's & Implementation of lean green practices & Thanki, S (2006) [21] \\
\hline $\begin{array}{ll}\text { Business } & \text { process } \\
\text { Management } & \end{array}$ & $\begin{array}{l}\text { Alternates for satisfaction and quality of } \\
\text { service }\end{array}$ & V. Kumar et.al., (2008) [22] \\
\hline SME's in Srilanka & $\begin{array}{l}\text { Business performance and quality of } \\
\text { service }\end{array}$ & $\begin{array}{l}\text { Wijetunge, W. A. D. S. } \\
\text { (2016) [23] }\end{array}$ \\
\hline
\end{tabular}

\section{RESEARCH METHODOLOGY:}

Type of research: The study which is carried out in the research is descriptive research whereby a lot of research is conducted on the service management of the automobile industry.

Data collection:

Primary data: The primary data was collected using the survey method and the respondents are those who are SME's doing business in the automobile industry and employees who are working with large scale companies in the automobile industry.

Secondary data: It was collected from journals and websites to know the concepts related to the study and to frame the conceptual framework of the study.

Sampling size:

A total of 50 companies who do get service from SME's were targeted and 110 employees who are working with those companies were taken as samples towards analyzing the commitment of suppliers.

Sampling design:

The samples were collected across Tamilnadu and they are as follows,

Table 2: Sampling design of the study

\begin{tabular}{|l|c|c|}
\hline \multicolumn{1}{|c|}{ District } & No of companies & No of employees \\
\hline Coimbatore & 10 & 23 \\
\hline Madurai & 6 & 17 \\
\hline Chennai & 24 & 48 \\
\hline Hosur & 10 & 22 \\
\hline Total & 50 & 110 \\
\hline
\end{tabular}




\section{Reliability Statistics:}

Table 3: Reliability of the study

\begin{tabular}{|l|c|c|}
\hline \multicolumn{1}{|c|}{ Dimension } & N of Items & Cronbach's Alpha \\
\hline Tangibility & 4 & .784 \\
\hline Reliability & 5 & .845 \\
\hline Responsiveness & 6 & .804 \\
\hline Assurance & 5 & .728 \\
\hline Empathy & 3 & .784 \\
\hline
\end{tabular}

A total of 10 samples were across all the districts taken for the study to check the reliability of the dimensions used for the study where the reliability for all the dimensions was greater than 0.7 which shows that the factors are reliable and can be proceeded further.

Tools used for the study: Frequency analysis, Descriptive statistic, Kruskal Wallis test, One-way Anova, and Multiple regression.

\section{LIMITATIONS OF THE STUDY:}

- Conclusions and recommendations are based on such limited data.

- Respondent's biases may be one of the factors which limit the study.

8. ANALYSIS AND INTERPRETATION PERCEPTION OF COMPANIES TOWARDS THEIR VENDORS:

Table 4: Type of Suppliers

\begin{tabular}{|l|r|r|}
\hline & Frequency & \multicolumn{1}{c|}{ Percent } \\
\hline New vendors & 35 & 70.0 \\
\hline Existing vendors & 15 & 30.0 \\
\hline Total & 50 & 100.0 \\
\hline
\end{tabular}

Out of 50 respondents $70.0 \%$ are new vendors, $30.0 \%$ are existing vendors.

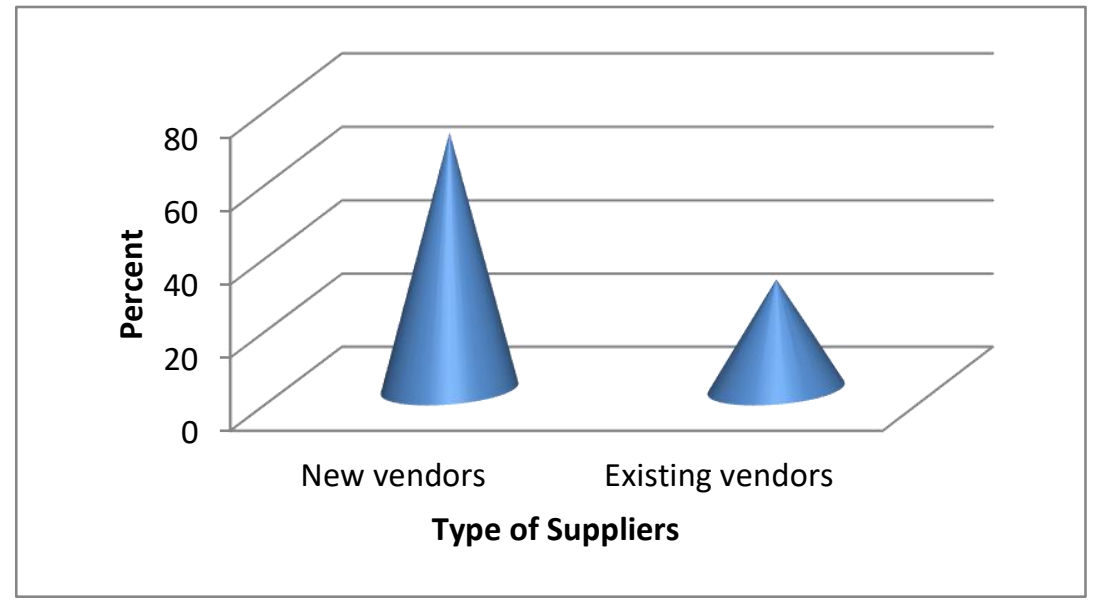

Chart 2: Type of Suppliers 
Table 5: No of years of having a relationship with Suppliers

\begin{tabular}{|l|r|r|}
\hline \multicolumn{1}{|c|}{ Particulars } & Frequency & \multicolumn{1}{c|}{ Percent } \\
\hline $1-3$ years & 1 & 2.7 \\
\hline 4-6 years & 18 & 36.7 \\
\hline 7-9 years & 16 & 31.3 \\
\hline More than 9 years & 15 & 29.3 \\
\hline Total & 50 & 100.0 \\
\hline
\end{tabular}

2.7\% are having between 1-3 years of relationship, $36.7 \%$ are having $4-6$ years of relationship, $31.3 \%$ are having 7-9 years of relationship, 29.3\% are having more than 9 years of relationship.

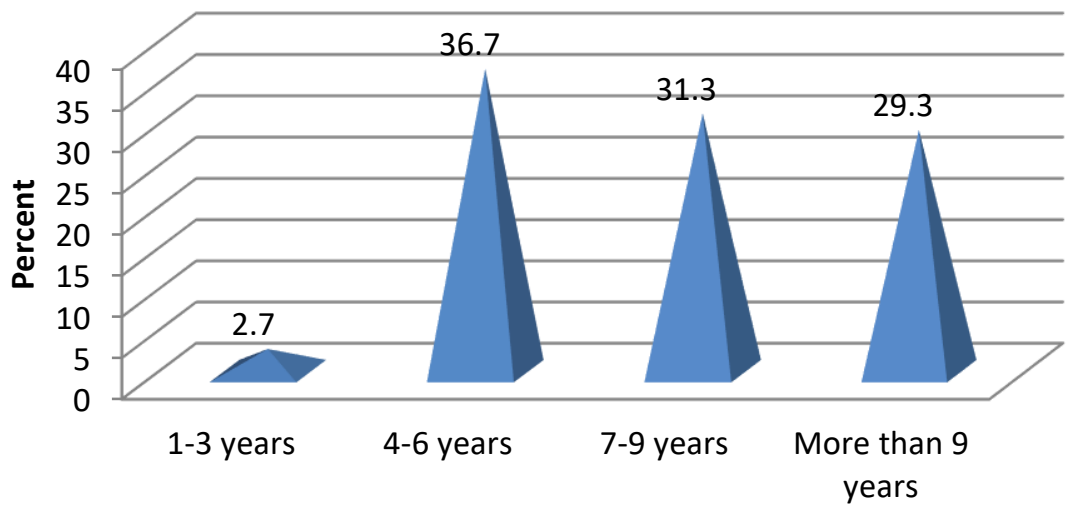

No of years having relationship with Suppliers

Chart no 3: No of years having a relationship with Suppliers

Table 6: Suppliers sales and service network better than competitor

\begin{tabular}{|l|r|r|}
\hline & Frequency & Percent \\
\hline Yes & 8 & 15.3 \\
\hline No & 18 & 36.0 \\
\hline Can be improved & 24 & 48.7 \\
\hline Total & 50 & 100.0 \\
\hline
\end{tabular}

15.3\% said Yes, $36.0 \%$ said No, and $48.7 \%$ said can be improved.

\section{Suppliers sales and service network better than competitor}

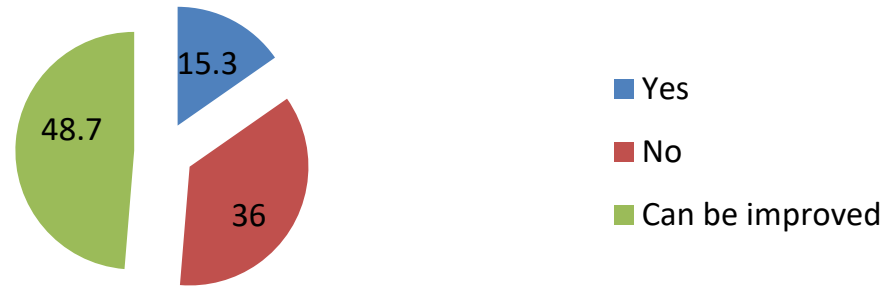

Chart no 4: Suppliers sales and service network better than competitor 
DESCRIPTIVE STATISTICS

Table 7: Perception of companies towards service quality with reference to tangibility

\begin{tabular}{|l|r|r|r|}
\hline Particulars & \multicolumn{1}{|c|}{$\mathbf{N}$} & Mean & \multicolumn{1}{c|}{ SD } \\
\hline TAN1 & 50 & 1.86 & .531 \\
\hline TAN2 & 50 & 2.05 & 1.006 \\
\hline TAN3 & 50 & 2.08 & .661 \\
\hline TAN4 & 50 & 1.59 & .494 \\
\hline
\end{tabular}

The companies said as very good for the availability of pamphlets regarding service specification by their vendor companies (2.05), professional appearance of the salespersons/service persons (2.08). Meanwhile, the respondents said as excellent for the appearance of the website (1.86) and pleasantness of their vendor companies.

Table 8: Perception of companies towards service quality with reference to reliability

\begin{tabular}{|l|r|r|r|}
\hline Particulars & \multicolumn{1}{|c|}{ N } & \multicolumn{1}{c|}{ Mean } & \multicolumn{1}{l|}{ SD } \\
\hline REL1 & 50 & 1.88 & 1.086 \\
\hline REL2 & 50 & 1.70 & .792 \\
\hline REL3 & 50 & 1.83 & .718 \\
\hline REL4 & 50 & 1.51 & .599 \\
\hline REL5 & 50 & 1.68 & .468 \\
\hline
\end{tabular}

The companies said as excellent for their vendors clearing doubts if questions were asked regarding product manufactured (1.88), time availability to give detailed information (1.70), time taken to prepare the template need by them (1.83), rectifying mistakes by service persons at the time of service (1.51) and proper information about the services rendered (1.68).

Table 9: Perception of companies towards service quality with reference to responsiveness

\begin{tabular}{|l|r|r|c|}
\hline \multicolumn{1}{|c|}{ Particulars } & \multicolumn{1}{c|}{ N } & Mean & SD \\
\hline RES1 & 50 & 1.80 & .695 \\
\hline RES2 & 50 & 2.03 & .536 \\
& & & \\
\hline RES3 & 50 & 1.76 & .587 \\
\hline RES4 & 50 & 1.99 & .675 \\
\hline RES5 & 50 & 1.79 & .869 \\
\hline RES6 & 50 & 1.89 & .860 \\
\hline
\end{tabular}

The companies said as excellent for politeness of the employees of their vendors (1.80), immediate attention by the service person (1.76), attentiveness in listening your queries (1.99), advice given regarding the necessary service (1.79) and promptness in delivery after service (1.89). Meanwhile, the companies in the automobile industry who outsource their work to SME's said as very good for companies showing interest in their need /requirements (2.03).

Table 10: Perception of companies towards service quality with reference to assurance

\begin{tabular}{|l|r|r|r|}
\hline \multicolumn{1}{|c|}{ Particulars } & \multicolumn{1}{c|}{ N } & \multicolumn{1}{c|}{ Mean } & \multicolumn{1}{c|}{ SD } \\
\hline ASS1 & 50 & 3.12 & 1.263 \\
\hline ASS2 & 50 & 3.30 & 1.241 \\
\hline ASS3 & 50 & 3.71 & 1.084 \\
\hline ASS4 & 50 & 3.93 & .984 \\
\hline ASS5 & 50 & 3.77 & 1.188 \\
\hline
\end{tabular}


The customers of the companies said as good for courtesy in servicing by the companies (3.12), inspecting the products (3.30), technical knowledge of service persons (3.71), usage of modern technology in servicing (3.93) and hospitality provided by the companies (3.93).

Table 11: Perception of companies towards service quality with reference to empathy

\begin{tabular}{|l|r|r|r|}
\hline Particulars & \multicolumn{1}{|c|}{$\mathbf{N}$} & \multicolumn{1}{c|}{ Mean } & \multicolumn{2}{c|}{ SD } \\
\hline EMP1 & 50 & 1.59 & .803 \\
\hline EMP2 & 50 & 1.90 & .775 \\
\hline EMP3 & 50 & 1.54 & .609 \\
\hline
\end{tabular}

The companies said as excellent for companies providing prior information about the service changes (1.59), explanation of the service provided (1.90) and reminder for renewal of service (1.54).

Ho1: Type of vendor has no relation with suppliers and degree of satisfaction towards services of the companies

Table 12: Comparison between type of vendor with suppliers and degree of satisfaction towards services of the companies companies

\begin{tabular}{|c|c|c|c|c|c|}
\hline Dimension & Type of vendor & $\mathbf{N}$ & Mean Rank & Chi-Square & Asymp. Sig. \\
\hline \multirow{3}{*}{ Tangibility } & New vendor & 35 & 75.16 & \multirow[t]{3}{*}{0.023} & \multirow[t]{3}{*}{0.880} \\
\hline & Existing vendor & 15 & 76.29 & & \\
\hline & Total & 50 & & & \\
\hline \multirow{3}{*}{ Reliability } & New vendor & 35 & 74.57 & \multirow[t]{3}{*}{0.168} & \multirow[t]{3}{*}{0.682} \\
\hline & Existing vendor & 15 & 77.68 & & \\
\hline & Total & 50 & & & \\
\hline \multirow{3}{*}{ Responsiveness } & New vendor & 35 & 76.00 & \multirow[t]{3}{*}{0.047} & \multirow[t]{3}{*}{0.828} \\
\hline & Existing vendor & 15 & 74.34 & & \\
\hline & Total & 50 & & & \\
\hline \multirow{3}{*}{ Assurance } & New vendor & 35 & 73.48 & \multirow[t]{3}{*}{0.776} & \multirow[t]{3}{*}{0.378} \\
\hline & Existing vendor & 15 & 80.22 & & \\
\hline & Total & 50 & & & \\
\hline \multirow{3}{*}{ Empathy } & New vendor & 35 & 73.10 & \multirow[t]{3}{*}{1.112} & \multirow[t]{3}{*}{0.292} \\
\hline & Existing vendor & 15 & 81.09 & & \\
\hline & Total & 50 & & & \\
\hline \multirow{3}{*}{ Social Responsibility } & New vendor & 35 & 70.97 & \multirow[t]{3}{*}{4.381} & \multirow[t]{3}{*}{0.036} \\
\hline & Existing vendor & 15 & 86.07 & & \\
\hline & Total & 50 & & & \\
\hline
\end{tabular}

There is no relationship between Tangibility (0.880), Reliability (0.682), Responsiveness (0.828), Assurance (0.378) and Empathy (0.292) and degree of satisfaction towards services of the companies. There is a relationship between Social Responsibility $(0.036)$ and degree of satisfaction towards services of the companies.

\section{ONEWAY ANOVA}

H02: There is a significant difference between no of years having a relationship with Suppliers and degree of satisfaction towards services of the companies. 
Table 13: Comparison between no of years having a relationship with suppliers and the degree of satisfaction towards services of the companies

\begin{tabular}{|c|c|c|c|c|c|c|}
\hline Dimension & No of years & $\mathbf{N}$ & Mean & SD & $\mathbf{F}$ & Sig \\
\hline \multirow{5}{*}{ Tangibility } & $1-3$ years & 4 & 2.75 & 0.000 & \multirow{5}{*}{4.204} & \multirow{5}{*}{0.007} \\
\hline & 4-6 years & 55 & 1.82 & 0.593 & & \\
\hline & 7-9 years & 47 & 1.96 & 0.401 & & \\
\hline & More than 9 years & 44 & 1.84 & 0.586 & & \\
\hline & Total & 50 & 1.89 & 0.548 & & \\
\hline \multirow{5}{*}{ Reliability } & $1-3$ years & 4 & 2.80 & 0.000 & \multirow{5}{*}{5.680} & \multirow{5}{*}{0.001} \\
\hline & 4-6 years & 55 & 1.75 & 0.640 & & \\
\hline & $7-9$ years & 47 & 1.58 & 0.436 & & \\
\hline & More than 9 years & 44 & 1.75 & 0.642 & & \\
\hline & Total & 50 & 1.72 & 0.603 & & \\
\hline \multirow{5}{*}{ Responsiveness } & $1-3$ years & 4 & 2.67 & 0.000 & \multirow{5}{*}{4.994} & \multirow{5}{*}{0.003} \\
\hline & 4-6 years & 55 & 1.75 & 0.568 & & \\
\hline & 7-9 years & 47 & 1.88 & 0.396 & & \\
\hline & More than 9 years & 44 & 1.96 & 0.511 & & \\
\hline & Total & 50 & 1.88 & 0.515 & & \\
\hline \multirow{5}{*}{ Assurance } & $1-3$ years & 4 & 2.80 & 0.000 & \multirow{5}{*}{1.764} & \multirow{5}{*}{0.157} \\
\hline & 4-6 years & 55 & 3.56 & 0.738 & & \\
\hline & 7-9 years & 47 & 3.51 & 0.815 & & \\
\hline & More than 9 years & 44 & 3.70 & 0.841 & & \\
\hline & Total & 50 & 3.57 & 0.803 & & \\
\hline \multirow{5}{*}{ Empathy } & $1-3$ years & 4 & 2.33 & 0.000 & \multirow{5}{*}{2.501} & \multirow{5}{*}{0.062} \\
\hline & 4-6 years & 55 & 1.72 & 0.564 & & \\
\hline & 7-9 years & 47 & 1.58 & 0.567 & & \\
\hline & More than 9 years & 44 & 1.67 & 0.516 & & \\
\hline & Total & 50 & 1.68 & 0.554 & & \\
\hline \multirow{5}{*}{ Social Responsibility } & 1-3 years & 4 & 1.50 & 0.000 & \multirow{5}{*}{0.184} & \multirow{5}{*}{0.907} \\
\hline & 4-6 years & 55 & 1.75 & 0.775 & & \\
\hline & 7-9 years & 47 & 1.72 & 0.666 & & \\
\hline & More than 9 years & 44 & 1.74 & 0.544 & & \\
\hline & Total & 50 & 1.73 & 0.665 & & \\
\hline
\end{tabular}

There is no significant difference between Tangibility (0.007), Reliability (0.001), and Responsiveness (0.003) and degree of satisfaction towards the services of the companies. There is a significant difference between Assurance (0.157), Empathy (0.062), and Social Responsibility (0.907) and degree of satisfaction towards services of the companies.

\section{Tangibility:}

The respondents who are having 1-3 years of relationship (2.75) said very good, and who are having 46 years (1.82), having 7-9 years (1.96), having More than 9 years (1.84) of relationship said Excellent on the degree of satisfaction towards services of the companies.

\section{Reliability:}


The respondents who are having 1-3 years of relationship (2.80) said very good, and who are having 46 years (1.75), having 7-9 years (1.58), having More than 9 years (1.75) of relationship said Excellent on the degree of satisfaction towards services of the companies.

\section{Responsiveness:}

The respondents who are having 1-3 years of relationship (2.67) said very good, and who are having 46 years (1.75), having 7-9 years (1.88), having More than 9 years (1.96) of relationship said Excellent on the degree of satisfaction towards services of the companies.

\section{PERCEPTION OF EMPLOYEE TOWARDS SERVICE PROVIDED BY SUPPLIERS}

Table 14: Age of the respondents

\begin{tabular}{|l|r|r|}
\hline Particulars & Frequency & \multicolumn{1}{|c|}{ Percent } \\
\hline Male & 65 & 59.1 \\
\hline Female & 15 & 40.9 \\
\hline Total & 110 & 100.0 \\
\hline
\end{tabular}

$59.1 \%$ are male, and $40.9 \%$ are female. It shows that most of the respondents are male gender.

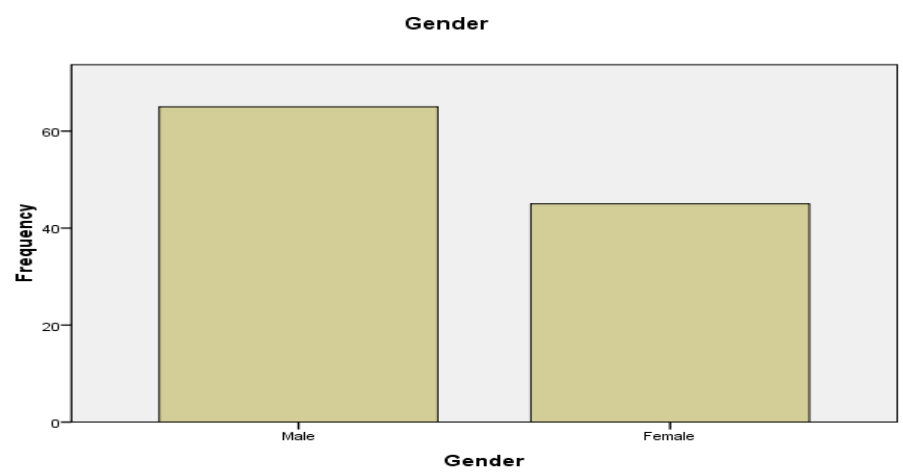

Chart no 5: Gender of the respondents

Table 15: Age of the employees

\begin{tabular}{|l|r|r|}
\hline Particulars & Frequency & Percent \\
\hline 20-30 years & 12 & 10.9 \\
\hline 31-40 years & 24 & 21.8 \\
\hline 41-50 years & 34 & 30.9 \\
\hline Above 50 years & 40 & 36.4 \\
\hline Total & 110 & 100.0 \\
\hline
\end{tabular}

$10.9 \%$ are between 20 to 30 years, $21.8 \%$ are between $31-40$ years, $30.9 \%$ are between $41-50$ years, and $36.4 \%$ are above 50 years. It shows that most of the respondents are from the age are above 50 years. 


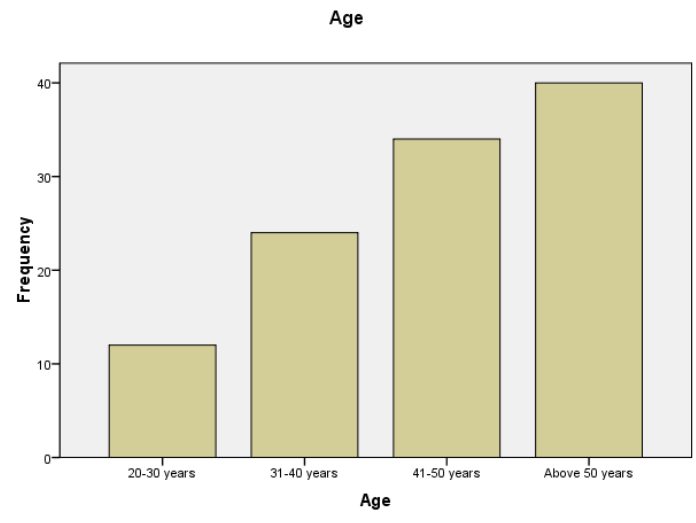

Chart no 6: Age of the respondents

Table 16: Prefer current suppliers

\begin{tabular}{|l|l|r|r|}
\hline Particulars & \multicolumn{1}{|c|}{ N } & \multicolumn{1}{c|}{ Mean } & \multicolumn{1}{|c|}{ SD } \\
\hline SUP1 & 110 & 2.15 & 1.35 \\
\hline SUP2 & 110 & 1.54 & .501 \\
\hline SUP3 & 110 & 2.46 & .738 \\
\hline SUP4 & 110 & 3.11 & 1.061 \\
\hline SUP5 & 110 & 2.83 & 1.374 \\
\hline SUP6 & 110 & 3.17 & 1.233 \\
\hline SUP7 & 110 & 3.21 & 1.212 \\
\hline
\end{tabular}

The respondents agree that current suppliers produces good looking products (2.15), suppliers produce clean products (2.46), and also current suppliers produce a wide variety of products (2.83), employees strongly agree that suppliers produce fresh products (1.54), respondents disagree towards the constant supply of produces throughout the year (3.11), suppliers produce are safe (3.17), and also towards the delivery of produces to their current outlet (3.21).

Table 17: Contact with current suppliers

\begin{tabular}{|l|l|r|r|}
\hline Particulars & \multicolumn{1}{|c|}{ N } & \multicolumn{1}{c|}{ Mean } & \multicolumn{1}{c|}{ SD } \\
\hline CON1 & 110 & 3.35 & 1.359 \\
\hline CON2 & 110 & 3.39 & 1.257 \\
\hline CON3 & 110 & 3.43 & 1.207 \\
\hline CON4 & 110 & 3.17 & 1.132 \\
\hline CON5 & 110 & 3.66 & 1.350 \\
\hline CON6 & 110 & 3.22 & 1.120 \\
\hline
\end{tabular}

The respondents disagree towards current suppliers known source of their produces (3.35), taking responsibility if produces has any problem (3.39), grading and packing of their produce (3.43), washing/peeling/cutting of their produces (3.17), having a long-term contract with current suppliers (3.66), and also towards the need of more qualified suppliers (3.22).

Ho3: There is a significant difference between the age of the respondents and the Preference for current suppliers and Contact with current suppliers by employees 
Table 18: Comparison between age and level of acceptance towards the preference on current suppliers and contact with current suppliers by employees

\begin{tabular}{|c|c|c|c|c|c|c|}
\hline Particulars & Age & $\mathbf{N}$ & Mean & SD & $\mathbf{F}$ & Sig \\
\hline \multirow{5}{*}{ Prefer current suppliers } & 20-30 years & 12 & 2.50 & 0.358 & \multirow{5}{*}{2.729} & \multirow{5}{*}{0.048} \\
\hline & $31-40$ years & 24 & 2.61 & 0.424 & & \\
\hline & $41-50$ years & 34 & 2.65 & 0.437 & & \\
\hline & Above 50 years & 40 & 2.81 & 0.308 & & \\
\hline & Total & 110 & 2.68 & 0.392 & & \\
\hline \multirow{5}{*}{$\begin{array}{c}\text { Contact with current } \\
\text { suppliers }\end{array}$} & 20-30 years & 12 & 3.13 & 0.742 & \multirow{5}{*}{6.395} & \multirow{5}{*}{0.001} \\
\hline & $31-40$ years & 24 & 3.13 & 0.567 & & \\
\hline & $41-50$ years & 34 & 3.33 & 0.414 & & \\
\hline & Above 50 years & 40 & 3.63 & 0.436 & & \\
\hline & Total & 110 & 3.37 & 0.536 & & \\
\hline
\end{tabular}

There is no significant difference between Preference on current suppliers (0.048), and Contact with current suppliers $(0.001)$ by employees.

Ho4: There is no relationship between gender and level of acceptance towards the Preference on current suppliers and Contact with current suppliers by employees.

Table 19: Comparison between gender and level of acceptance towards the Preference on current suppliers and Contact with current suppliers by employees

\begin{tabular}{|l|l|r|r|r|r|}
\hline \multicolumn{1}{|c|}{ Particulars } & Gender & N & Mean Rank & Chi-Square & Asymp. Sig \\
\hline Prefer current suppliers & Male & 65 & 54.89 & 0.058 & 0.809 \\
\cline { 2 - 5 } & Female & 15 & 56.38 & & \\
\cline { 2 - 4 } & Total & 110 & & & \\
\hline \multirow{2}{*}{$\begin{array}{l}\text { Contact with current } \\
\text { suppliers }\end{array}$} & Male & 65 & 57.56 & 0.674 & 0.412 \\
\cline { 2 - 4 } & Female & 15 & 52.52 & & \\
\cline { 2 - 4 } & Total & 110 & & & \\
\hline
\end{tabular}

There is no relationship between Preference on current suppliers (0.809), and Contact with current suppliers $(0.412)$ by employees.

The chart 7 describes that when analysing the service quality of the companies and preference towards current suppliers were the factors reliability (.220), responsiveness (.422), assurance (.018) are directly having relationship and impact on preference towards current suppliers. Meanwhile, the dimensions tangibility (.057) and reliability (.609) are directly having a relationship and impact on contact with current suppliers.

\section{FINDINGS:}

\section{PERCEPTION OF VENDOR TOWARDS SERVICE QUALITY PROVIDED BY SUPPLIERS}

- Most of the respondents are new vendors.

- Maximum of the respondents are having 4-6 years of relationship with Suppliers.

- Most of the respondents got the reference to Suppliers through friends.

- Maximum of the respondents said that Suppliers sales and service networks can be improved better than their competitors in Coimbatore.

- Maximum of the respondents said as no to continue their service with Suppliers. 
- Most of the respondents said yes they will recommend Suppliers to friends \& relatives.

- Maximum of the respondents are Neutral on their Satisfaction towards getting orders from the global market.

- Most of the respondents are dissatisfied with the satisfaction level in helping the vendors for promoting the product based on their scheme.

The vendors of the companies said as very good for the availability of pamphlets regarding service specification, professional appearance of the salespersons/service persons. Meanwhile, the respondents said as excellent for the appearance of the website and pleasantness

The vendors of the companies said as excellent for companies clearing doubts, time availability to give detailed information, Time taken to prepare the template, rectifying mistakes by service persons and proper information about the services rendered.

\section{MULTIPLE REGRESSION}

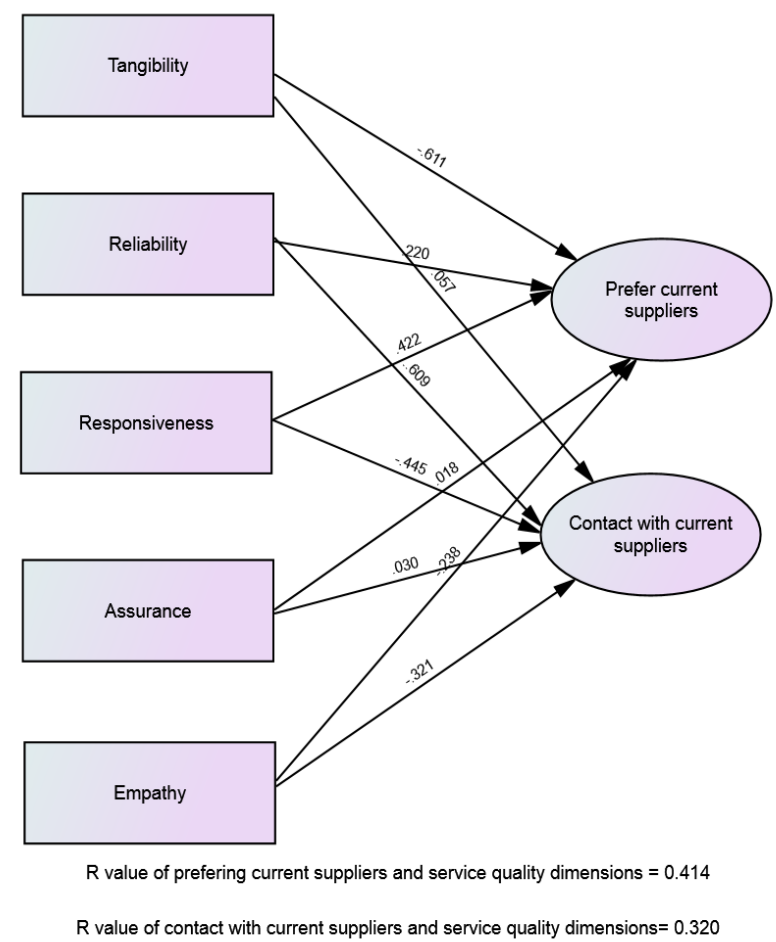

Chart 7: Comparison between service quality of the companies and perception of employees towards suppliers

The vendors of the companies said as excellent for the politeness of the employees, immediate attention by the service person, attentiveness in listening to your queries, Advice given regarding the necessary service and promptness in delivery after service. Meanwhile, the vendors of Suppliers said as very good for companies showing interest in vendors' needs/requirements.

The vendors of the companies said as good for courtesy in servicing by the companies, inspecting the products, technical knowledge of service persons, usage of modern technology in servicing and hospitality provided by the companies.

The vendors of the companies said as excellent for companies providing prior information about the service changes, Explanation of the service provided and reminder for renewal of service.

The vendors of the companies said as excellent for the cost of service of the companies and after service performance of the products of the companies. 
The respondents who are Existing vendors have a higher level of acceptance towards the degree of satisfaction towards the services of the companies.

\section{Tangibility:}

The respondents who are having 1-3 years of relationship said very good, and who are having 4-6 years, having 7-9 years, having More than 9 years of relationship said Excellent on the degree of satisfaction towards services of the companies.

\section{Reliability:}

The respondents who are having 1-3 years of relationship said very good, and who are having 4-6 years, having 7-9 years, having More than 9 years of relationship said Excellent on the degree of satisfaction towards services of the companies.

\section{Responsiveness:}

The respondents who are having 1-3 years of relationship said very good, and who are having 4-6 years, having 7-9 years, having More than 9 years of relationship said Excellent on the degree of satisfaction towards services of the companies.

\section{PERCEPTION OF EMPLOYEE TOWARDS SERVICE PROVIDED BY SUPPLIERS :}

- Most of the respondents are male gender.

- Most of the respondents are married.

- Most of the respondents are from the age are above 50 years.

The respondents agree that current suppliers produce good looking products, suppliers produce clean products, and also current suppliers produces wide variety of products, employees strongly agree that suppliers produce fresh products, respondents disagree towards constant supply of produces throughout the year, suppliers produce are safe, and also towards delivery of produces to their current outlet.

The respondents disagree towards current suppliers known source of their produces, taking responsibility if produces has any problem, grading and packing of their produces, washing/peeling/cutting of their produces, having a long-term contract with current suppliers, and also towards need of more qualified suppliers.

\section{Prefer current suppliers:}

The respondents who are in the age group between 20-30 years, age group between 31-40 years, age group between 41-50 years, and above 50 years agree towards Preference on current suppliers by employees.

\section{Contact with current suppliers:}

The respondents who are in the age group between 20-30 years, age group between 31-40 years, age group between 41-50 years, and above 50 years disagree towards Contact with current suppliers by employees.

\section{Contact with current suppliers:}

The respondents who are male (57.56) have a higher level of acceptance towards the Preference on current suppliers and Contact with current suppliers by employees.

The factors reliability, responsiveness, assurance are directly having a relationship and impact on preference towards current suppliers. Meanwhile, the dimensions tangibility and reliability are directly having a relationship and impact on contact with current suppliers.

\section{SUGGESTIONS:}

- Sales and operations planning must span the entire chain to detect early warning signals of changing demand in ordering patterns, vendor promotions, and so forth. This demand-intensive approach leads to more consistent forecasts and optimal resource allocation. 
- By working closely with their key suppliers to reduce the overall costs of owning materials and services, supply-chain management leaders enhance margins both for themselves and their suppliers.

- Vendors Feedback has to be collected in order to know the strong and weak areas in their service which will help them to correct and function well in the future.

- The dimensional factors level of acceptance towards sourcing product from a limited number of suppliers, level of acceptance towards establishing clear criteria and level of acceptance towards Suppliers collaborating with suppliers in materials are taken for decision making process of the study.

\section{CONCLUSION:}

The conclusion is that dimensional factors level of acceptance towards sourcing products from a limited number of suppliers, level of acceptance towards establishing clear criteria, and level of acceptance towards Suppliers collaborating with suppliers in materials are taken for decision making process of the study. It also reveals that while taking decisions on these dimensions the factor frequency of making supply should be taken for decision making process of the study.

\section{REFERENCES:}

[1] Baidoo, F., \& Odum-Awuakye, G. A. (2015). Influence of Service Quality Delivery in the SMEs of The Motor Vehicle Repair Service Industry in Ghana. African Journal of Applied Research (AJAR), 1(1), 440-452.

[2] Baidoo, F., \& Odum-Awuakye, G. A. (2017). Assessing customer satisfaction levels in the SMEs automobile vehicle maintenance and repairs service delivery system in Cape Coast-Ghana. African Journal of Applied Research (AJAR), 3(1), 82-94.

[3] Bruce C.Y. Lee \& Ching-Chin Chen et. al., (2019). The influence of service quality on customer satisfaction and loyalty in B2B technology service industry. Total Quality Management \& Business Excellence, 30, 13-14.

[4] Dharmaraj, C. and J Clement Sudhahar (2009). Brand preference Factors of Passenger bike an empirical assessment. The IUP Journal Management, 7(3), 19 - 33.

[5] Cerchione, R., Esposito, E., \& Spadaro, M. R. (2016). A literature review on knowledge management in SMEs. Knowledge Management Research \& Practice, 14(2), 169-177.

[6] Ebrahimi, M., \& Sadeghi, M. (2013). Quality management and performance: An annotated review. International Journal of Production Research, 51(18), 5625-5643.

[7] Sureshchandar, G. S. Chandrasekharan Rajendran, Anantharaman, R. N. (2002). The relationship between service quality and customer satisfaction - a factor specific approach. Journal of Services Marketing, 16(4), 363 - 379.

[8] Gandhi, S. K., Sachdeva, A., \& Gupta, A. (2017). Treat employees like customers for an achievement culture: an intrinsic service quality perspective from Indian SMEs. Journal of Industrial Engineering and Advances, 2(3), 1-10.

[9] Gandhi, S., Sachdeva, A., \& Gupta, A. (2018). Developing a scale to measure employee service quality in Indian SMEs. Management Science Letters, 8(5), 455-474.

[10] Agarwal, J., Malhotra, N. K., \& Bolton, R. N. (2010). A cross-national and cross-cultural approach to global market segmentation: An application using consumers' perceived service quality. Journal of International Marketing, 18(3), 18-40.

[11] Jayawardhena, C. (2018). Effects of retail employees' behaviors on customers 'service evaluation. International Journal of Retail \& Distribution Management, 39 (3), 203-217. 
[12] Kalra, N., \& Pant, A. (2013). TQM-A Management Philosophy in Indian Automobile Industry (NCR). International Journal of Management (IJM), 4(6), 12-20.

[13] Kantabutra Sooksan. (2008), Vision Effects in Thai Retail Stores: Practical Implications. International Journal of Retail \& Distribution Management, 36(4), 323-342.

[14] Kowalkowski, C., Witell, L., \& Gustafsson, A. (2013). Any way goes: Identifying value constellations for service infusion in SMEs. Industrial Marketing Management, 42(1), 18-30.

[15] Krishnaswamy, K. N., Mathirajan, M., \& Subrahmanya, M. B. (2014). Technological innovations and its influence on the growth of auto component SMEs of Bangalore: A case study approach. Technology in Society, 38, 18-31.

[16] Mishra Kumar Rohit (2014). Benchmarking Scheme for Retail Stores Efficiency. International Journal of marketing Studies, 1(2), 131-150.

[17] Rajić, T., Nikolić, I., \& Milošević, I. (2016). The antecedents of SMEs' customer loyalty: Examining the role of service quality, satisfaction and trust. Industrija, 44(3), 97-116.

[18] Ramezani, H., \& Gharleghi, B. (2013). Determinants of the Total Quality Management Implementation in SMEs in Iran (Case of Metal Industry). International Journal of Business and Social Science, 4(16).

[19] Spiros Gounaris (2005). Measuring service quality in b2b services: an evaluation of the SERVQUAL scale vis-a '-vis the INDSERV scale. Journal of Services Marketing, 19 (6),421-435.

[20] Subroto Budiarto and Putra Seven Freddy. (2008). The Influence of Retailing Mix and Service Quality towards Customer Satisfaction and Their Impact to Behavioral Intentions. Journal of Service Research, 8, 232-240.

[21] Tangkitvanich, S. (2004). SME development in Thailand's automotive industry. Entrepreneurship and SMEs in Southeast Asia, 206-220.

[22] Thanki, S., Govindan, K., \& Thakkar, J. (2016). An investigation on lean-green implementation practices in Indian SMEs using analytical hierarchy process (AHP) approach. Journal of Cleaner Production, 135, 284-298.

[23] V. Kumar, P.A. Smart, H. Maddern, R.S. Maull, (2008). Alternative perspectives on service quality and customer satisfaction: the role of BPM. International Journal of Service Industry Management, 19 (2), $176-187$.

[24] Wijetunge, W. A. D. S. (2016). Service quality, competitive advantage and business performance in service providing SMEs in Sri Lanka. International Journal of Scientific and Research Publications, 6(7), 720-728. 